\section{1. 化学療法の副作用管理}

九州大学脳神経外科
棌村 孝紀, 中溝 玲, 池崎 清信,
福井 仁士

化学療法の合併症は, 出現してから治療を行うのではなく, 合併症を抑制する管理が重要である。ここでは脳腫瘍で用い られる代表的化学療法剤の副作用の予防法と管理法, 特に輸 液管理，副作用抑制剂の投与法について紹介する（骨髄抑制 は除く）。嘔気，嘔吐は患者が最も負担に思う副作用であり， 症状の出現しやすさは薬郕によって異なり個人差もある. cisplatinは抗腫瘍凨のなかで最も嘔気，嘔吐が出現しやすい 薬剂であるが，5-HT3 blocker投与を行うだけでなく，薬凨 の投与方法，時間を工夫することでかなり抑制できる。また 腎障害も出現しやすい副作用である。 methotrexateの大量療 法が中枢性悪性リンパ腫で良好な成績を示しているが， methotrexate は腎から排泄され，尿の $\mathrm{pH}$ が低下すると腎尿 細管で析出して腎障害を招くので，尿の $\mathrm{pH}$ 管理と尿量を維 持する管理が必要である。 cisplatinも一定量以上の尿量を維 持する管理を要する。このように化学療法剤の投与には薬剤 によってきめ細かい管理が必要であり，プロトコールどおり に管理すればよいのではなく，それぞれの薬剤の特性を熟知 して治療にあたらねばならない。

\section{2. 悪性脳腫瘍における抗癌剤の標準使用と副作用 に対する治療}

\section{愛媛大学脳神経外科 \\ 大西 丘倫}

悪性脳腫愓に対する化学療法の要点として，血液脳関門と 腫瘍感受性を考慮した有効な薬剤の選択と最適な治療域の薬 剂投与があげられる。しかし，程度の差こそあれ，副作用と しての骨髄抑制は，しばしば治療実践時の大きな障壁となる。 ここでは，そのような副作用に対処するため，重篤な骨䯣抑 制の発症を最小限にするための工夫と副作用発症後の対策 · 治療について述べる。まず，使用頻度が高いCBDCAについ ては，本抗癌剈がその薬物動態力学上，腎血流にのみ依存し ていることより，患者の体重や体表面積ではなく，糸球体濾 過率の測定に基づいた一定の計算式より至適投与量を決定す ることができる，特に，骨䯣機能が十分回復していない時期 での 2 コース目以降の化学療法を行う時や，末梢血幹細胞移 植を用いて大量化学療法を行う時の用量決定には非常に有用 である。一方，抗癌剤投与後の骨髄抑制のうち顆粒球減少に 対しては，rhG-CSFの投与により nadirの底上げ効果や白血 球滅少の期間短縮を期待できるようになった。ただしその至 適投与法を考慮する必要がある。また，顆粒球数が $100 /$ $\mathrm{mm} 3$ 以下になると，ガウンテクニック，アイソレーターの 使用の他に，適切な抗菌剤の投与により感染症を未然に防ぐ
努力が必要である.

\section{Neoro-oncology と保険医療制度}

㕕島大学脳神経外科

杉山一彦

現状分析：本邦における悪性脳腫痬患者に投与可能な抗腫 瘍剂は，きわめて限定されている。厳密な意味では化学療法 に対して高い反応性を示す頭蓋内胚細胞性腫痬（GCT）に 対しても，白金製剤は投与できない。これを保険医療の弾力 的運用で可能にしても，財政的な面から今後これ困難にこそ なれ，緩やかになることはないであろう。また，同一保険で の地域差という問題も生じ得る。一方で，今回 G-CSFの適 応拡大時に，はじめて病理学的 entity としてのGCTが取り 入れられた。病理学的 entityで保険適応が示される優位性は, 悪性リンパ腫と他の脳腫場を考えてみればよくわかる。

今後への展望：これまでに本邦で行われた prospective studyをもつて, 稀少疾病用薬品（1993年8月 25 日厚生省薬 発 725 号)，疾患適応外薬品（1999年 2 月 1 日厚生省通達）な どの制度を利用して，抗腫瘍剤を保険医療上使用可能にする ことが考兄られる。また，適応拡大を目的とした単剂の phase II studyも可能であろう。現実的には頭蓋内GCTに対

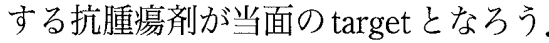

まとめ: 保険医療から 21 世紀の本邦の脳腫瘍治療をみる とき，峳密な prospective study，phase studyを行う実力をも つ医療者を育成するシステム確立が急務である。

\section{4. 脳卒中患者に適した降圧剤}

島根医科大学第 3 内科 小林 祥泰

脳梗塞急性期においては，16\%以上の降圧で脳血流低下 がみられるという報告等があり，降圧療法は行わないのが原 則である。脳卒中慢性期でも，脳循環自動調節能が障害され ているので, 血圧は高めに維持すべきという意見が根強いが, Irieらの報告では，脳出血は血圧が高いほど直線的に再発が 増加し，脳梗塞でも収縮期血圧が高いほど再発が多く，拡張 期血圧のみでJカーブ現象がみられている（アテローム血栓 の最適值；85～89，ラクナ梗塞；80～85 mmHg). 発症前血 圧の検討でも $150 / 90 \mathrm{mmHg}$ を境に脳卒中が増加することか ら, AHA99では $140 / 90 \mathrm{mmHg}$ 以下に管理することを推奨し ている。また，夜間高血圧，血圧変動も再発の危険因子とさ れている。したがって，降圧剤は緩徐かつ長時間作用型が第 一選択となる。欧米の一次予防の大規模研究では，降圧剤の 種類よりも降圧そのものの効果が大きいとされているが，最 近では ACE 阻害薬の動脈硬化抑制作用が注目され，脳卒中 二次予防の大規模な PROGRESS 研究が完了に近づいている. $\mathrm{ACE}$ 阻害薬およびCa 拮抗薬の一部では，脳循環改善作用も 